\author{
Jurnal E-KOMTEK (Elektro-Komputer-Teknik) \\ Vol. 4, No. 2 (2020) pp. 115-126 \\ https://jurnal.politeknik-kebumen.ac.id/index.php/E-KOMTEK \\ p-ISSN : 2580-3719 e-ISSN : 2622-3066
}

\title{
Sistem Pendukung Keputusan Kelayakan Penerima Hadiah Tahunan Menggunakan Metode Simple Additive Weighting (SAW) Berbasis Android (Studi Kasus: Koperasi Bunda Gandasari)
}

\author{
Nenny Anggraini ${ }^{1 *}$, Siti Ummi Masruroh2, Muhammad Yusuf Nurpariz ${ }^{3}$, Ariq Cahya \\ Wardhana ${ }^{4}$ \\ 1,2,3Teknik Informatika, Universitas Islam Negeri Syarif Hidayatullah, Jakarta, Indonesia, 15412 \\ ${ }^{4}$ Rekayasa Perangkat Lunak, Institut Teknologi Telkom Purwokerto, Purwokerto, Indonesia, 53147
}

*E-mail : nenny.anggraini@uinjkt.ac.id

Doi $\quad$ : https://doi.org/10.37339/e-komtek.v4i2.236

Diterbitkan oleh Politeknik Dharma Patria Kebumen

\section{Info Artikel \\ Diterima : \\ 17-06-2020 \\ Diperbaiki : \\ 12-11-2020 \\ Disetujui : \\ $12-11-2020$}

\begin{abstract}
ABSTRAK
Guna mempertahankan dan memotivasi anggota serta menarik non anggota menjadi anggota, koperasi Bunda mempunyai program kerja yaitu pemberian hadiah kepada anggota setiap tahunnya. Penentuan penerima hadiah, koperasi Bunda masih menggunakan cara manual yaitu melakukan pengundian, yang berpotensi terpilihnya anggota yang berkontribusi minimum yang dinilai kurang layak untuk menerima hadiah. Penentuan kelayakan penerima hadiah pengurus koperasi memberikan standar kriteria yaitu besarnya jumlah pinjaman, banyaknya jumlah tabungan, transaksi menabung, lama menjadi anggota dan banyaknya membawa nasabah non anggota. Upaya membantu koperasi menentukan anggota yang layak menerima hadiah, diperlukan sebuah sistem pendukung keputusan. Sistem dirancang mengggunakan metode Simple Additive Weighting (SAW) yang merupakan salah satu metode Multiple Attribute Decision Making (MADM). Hasil penelitian ini menyatakan bahwa dari 10 data sampel anggota koperasi, didapat nilai

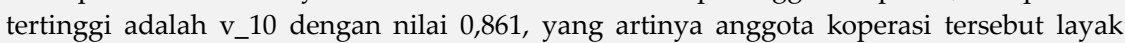
menerima hadiah tahunan dari pihak koperasi.

Kata kunci: Koperasi; Sistem Pendukung Keputusan; Algoritma Simple Additive Weighting
\end{abstract}

\section{ABSTRACT}

In order to maintain and motivate members and attract non-members to become members, the Bunda cooperative has a work program, namely giving gifts to members every year. In determining the prize recipient, the Bunda cooperative still uses the manual method, namely by conducting a draw, which has the potential to elect members who contribute the minimum who are deemed not worthy of receiving the prize. In determining the eligibility of the prize recipient, the cooperative management provides standard criteria, namely the amount of the loan, the amount of savings, the number of savings transactions, the length of time being a member and the number of bringing in non-member customers. In an effort to help cooperatives determine which members are eligible for prizes, a decision support system is needed. The system is designed to use the Simple Additive Weighting (SAW) method, which is one of the Multiple Attribute Decision Making (MADM) methods. The results of this study indicate that from 10 sample data of cooperative members, the highest score is $v \_10$ with a value of 0.861 , which means that the cooperative members deserve to receive an annual prize from the cooperative.

Keywords: Cooperative; Decision Support System; Simple Additive Weighting Algorithm 


\section{PENDAHULUAN}

Koperasi merupakan satu-satunya bentuk usaha yang termuat dalam Pasal 33 ayat (1) Undang- Undang Dasar Negara Republik Indonesia Tahun 1945 ditegaskan bahwa "perekonomian disusun sebagai usaha bersama berdasar atas asas kekeluargaan". Ketentuan tersebut sesuai dengan prinsip koperasi, karena itu koperasi mendapat misi untuk berperan nyata dalam menyusun perekonomian yang berdasar atas asas kekeluargaan dan demokrasi ekonomi yang mengutamakan kemakmuran masyarakat bukan kemakmuran orang-seorang. Koperasi tidak hanya merupakan satu-satunya bentuk perusahaan yang secara konstitusional dinyatakan sesuai dengan susunan 2 perekonomian yang hendak dibangun di negeri ini, tapi juga dinyatakan sebagai sokoguru perekonomian nasional [1].

Dalam rangka melaksanakan pembangunan terhadap koperasi agar mampu berkembang menjadi koperasi yang berkualitas, dan berprestasi, maka berbagai program dan kegiatan telah dilaksanakan. Salah satu sebagai pedoman koperasi berprestasi dengan melihat dan mensurvei anggota koperasi tersebut. Salah satu program kegiatan yang dilaksanakan setiap tahun adalah kegiatan penilaian anggota koperasi berprestasi, untuk diberikan penghargaan atas keikutsertaan dan keberhasilan anggota koperasi dalam menjalankan usaha [1].

Koperasi Bunga Gandasari (Koperasi Bunda) yang berdiri pada tanggal 27 April 2006 terletak di Desa Gandasari, Kec. Cikarang Barat - Kab. Bekasi. Koperasi ini merupakan koperasi wanita yang bergerak dalam bidang Simpan dan Pinjam. Saat ini koperasi Bunda dipimpin oleh 5 orang pengurus dan mempunyai anggota sebanyak 625 orang/ tanggal 10 April 2018. Adapun peran dan fungsi koperasi Bunda yaitu untuk meningkatkan tatanan perekonomian masyarakat dalam rangka mewujudkan masyarakat yang maju dan berdasarkan asas kekeluargaan dan berperan serta secara aktif dalam upaya mempertinggi kualitas kehidupan manusia dan masyarakat.

Menurut ibu mulyanah selaku ketua "Koperasi Bunda, mempunyai beberapa program kerja salah satunya adalah pemberian hadiah untuk anggota setiap tahunnya. Program kerja tersebut bertujuan untuk mempertahankan dan memotivasi anggota serta menarik minat non anggota menjadi anggotav. Namun, pada proses pemberian hadiah pihak koperasi masih mempunyai masalah. Permasalahan tersebut yaitu dalam menentukan penerima hadiah pihak koperasi masih menggunakan cara manual yaitu dengan melakukan pengundian. Cara tersebut berpotensi terpilihnya anggota koperasi yang mempunyai kontribusi minimum yang dinilai 
(c) Nenny Anggraini, Siti Ummi Masruroh, Muhammad Yusuf Nurpariz, Ariq Cahya Wardhana

kurang layak untuk menerima hadiah. Guna mengatasi masalah tersebut, koperasi membutuhkan sebuah sistem yang dapat membantu dalam memberikan keputusan kelayakan penerima hadiah.

Berdasarkan Dalam menentukan kelayakan penerima hadiah pihak koperasi memberikan standar dan bobot kriteria penerima hadiah dimana kriteria tersebut yaitu besarnya jumlah pinjaman dengan bobot $30 \%$, banyaknya jumlah tabungan $25 \%$, banyaknya transaksi menabung $20 \%$, lama menjadi anggota $15 \%$ dan banyaknya membawa nasabah non anggota $10 \%$.

Decision Support System atau Sistem Pendukung Keputusan merupakan suatu sistem informasi berbasis komputer yang interaktif, fleksibel, dan mudah diadaptasi, dimana sistem pendukung keputusan ini memanfaatkan rule keputusan, model, dan model yang telah ditambahkan dengan database komprehensif yang mampu membuat keputusan sendiri yang lebih spesifik, sehingga dapat disimpulkan bahwa sistem pendukung keputusan ini dapat mendukung pengambilan keputusan yang kompleks [2].

Ada beberapa metode yang digunakan untuk pengambilan keputusan, diantaranya Analytical Hierarchy Process (AHP), Simple Addative Weighting (SAW), dan Technique for Order Preference by Similiarity to Ideal Solution (TOPSIS). Pada penelitian ini penulis menggunakan metode Simple Additive Weighting. Metode SAW sering juga dikenal dengan istilah metode penjumlahan terbobo. Konsep dasar metode SAW adalah mencari penjumlahan terbobot dari rating kinerja pada setiap alternatif pada semua atribut. Metode SAW membutuhkan proses normalisasi matriks keputusan $(X)$ ke suatu skala yang dapat diperbandingkan dengan semua rating alternatif yang ada [3].

Metode ini merupakan metode yang paling terkenal dan paling banyak digunakan dalam menghadapi situasi Multiple Attribute Decision Making (MADM). MADM itu sendiri merupakan suatu metode yang digunakan untuk mencari alternatif optimal dari sejumlah alternatif dengan kriteria tertentu. Metode SAW ini mengharuskan pembuat keputusan menentukan bobot dari setiap atribut. Skor total untuk alternatif diperoleh dengan menjumlahkan seluruh hasil perkalian antara rating (yang dapat dibandingkan lintas atribut) dan bobot tiap atribut. Rating tiap atribut haruslah bebas dimensi dalam arti telah melewati proses normalisasi sebelumnya [3].

Android merupakan platform lengkap mulai dari sistem operasi, tool developing, aplikasi, market aplikasi bahkan dukungan dari komunitas Open System. Oleh karena itu, ini merupakan 
keunggulan yang tidak dimiliki platform lain. Menurut data yang dirilis oleh Statista menunjukkan pangsa pasar global OS seluler, dalam hal penjualan ke pengguna akhir, dari 2009 hingga 2018. Pada tahun 2018, 88 persen dari semua smartphone yang dijual kepada pengguna akhir adalah ponsel dengan sistem operasi Android. Grafik penjualan smartphone dari tahun 2009 sampai 2018 disajikan pada Gambar 1.

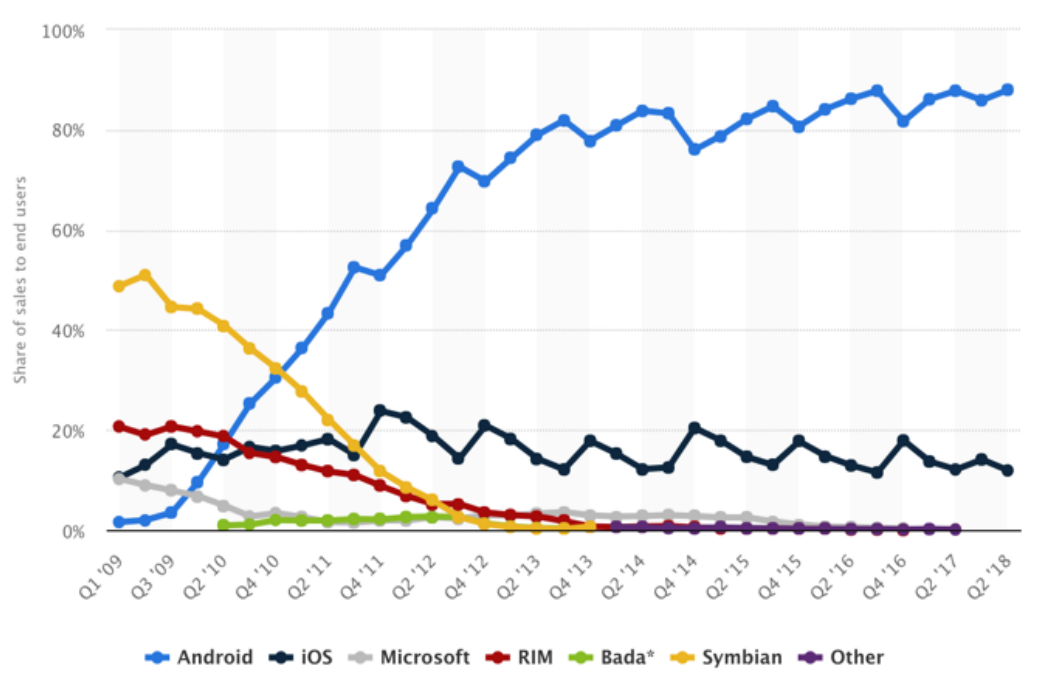

Gambar 1. Pangsa Pasar Global OS Seluler [3]

Dari hasil analisis, studi literatur, dan wawancara maka solusi berdasarkan masalah yang ada dan kebutuhan pihak koperasi Bunda yaitu membuat suatu aplikasi sistem pendukung keputusan kelayakan penerima hadiah pada anggota koperasi menggunakan perangkat mobile (Android). Metode yang digunakan menggunakan Simple Additive Weighting (SAW).

\section{MATERIAL DAN METODE}

\subsection{Material}

\subsubsection{Sistem Pendukung Keputusan}

Menurut Latif, Jamil, \& Abbas menyatakan bahwa konsep Sistem Pendukung Keputusan pertama kali diungkapkan pada tahun 1971 oleh Michael Scoot Morton dengan istilah Management Decision System. Kemudian sejumlah perusahaan, lembaga penelitian dan perguruan tinggi mulai melakukan penelitian dan membangun sistem pendukung keputusan, sehingga dari produksi yang dihasilkan dapat disimpulkan bahwa sistem ini merupakan suatu sistem berbasis komputer yang ditujukan untuk membantu pengambilan keputusan dalam memanfaatkan data dan model tertentu untuk memecahkan berbagai persoalan yang tidak terstruktur [4]. 
(c) Nenny Anggraini, Siti Ummi Masruroh, Muhammad Yusuf Nurpariz, Ariq Cahya Wardhana

\subsubsection{Simple Additive Weighting (SAW)}

Metode Simple Additive Weighting (SAW) adalah suatu metode yang digunakan untuk mencari alternatif optimal dari sejumlah alternatif dengan kriteria tertentu. Metode simple additive weighting (SAW) sering juga dikenal dengan istilah metode penjumlahan terbobot. Konsep dasar metode SAW adalah mencari penjumlahan terbobot dari rating kinerja pada setiap alternatif pada semua kriteria. Perhitungan dengan metode SAW akan menghasilkan nilai terbesar yang akan dijadikan alternatif terbaik. Dalam metode SAW, pembuat keputusan menentukan kriteria dan bobot untuk setiap kriteria.Metode SAW membutuhkan proses normalisasi matrik keputusan $(X)$ ke suatu skala yang dapat diperbandingkan dengan semua rating alternatif yang ada [5].

Metode ini merupakan metode yang paling terkenal dan paling banyak digunakan dalam menghadapi situasi Multiple Attribute Decision Making (MADM). MADM itu sendiri merupakan suatu metode yang digunakan untuk mencari alternatif optimal dari sejumlah alternatif dengan kriteria tertentu.Langkah penyelesaian SAW sebagai berikut [5].

a. Menentukan alternatif, yaitu Ai.

b. Menentukan kriteria-kriteria yang akan dijadikan acuan dalam pengambilan keputusan, yaitu Ci.

c. Menentukan rating kecocokan setiap alternatif pada setiap kriteria.

d. Menentukan bobot preferensi atau tingkat kepentingan (W) setiap kriteria $W=[W 1$ W2 W3 W4].

e. Membuat tabel rating kecocokan dari setiap alternatif pada setiap kriteria.

f. Membuat matrik keputusan yang dibentuk dari tabel rating kecocokan dari setiap alternatif pada setiap kriteria nilai setiap alternatif (Ai) pada setiap kriteria (Cj) yang sudah ditentukan, dimana $i=1,2$ m dan $j=1,2, . . n$

g. Melakukan normalisasi matrik keputusan dengan cara menghitung nilai rating kinerja ternormalisasi (rij) dan alternatif Ai pada kriteria Cj.Formula untuk melakukan normalisasi tersebut adalah sebagai berikut:

h. Hasil dari nilai rating kerja ternormalisasi (rij) membentuk matrik ternormalisasi (R).

i. Hasil akhir dari preferensi (Vi) diperoleh dari penjumlahan dari perkalian elemen baris matrik ternormalisasi $(\mathrm{R})$ dengan bobot preferensi $(\mathrm{W})$ yang bersesuai elemen kolom matrik $(\mathrm{W})$. 
(c) Nenny Anggraini, Siti Ummi Masruroh, Muhammad Yusuf Nurpariz, Ariq Cahya Wardhana

Nilai preferensi untuk setiap alternatif (Vi) disajikan pada Gambar 2.

$$
\mathrm{V}_{\mathrm{i}}=\sum_{\mathrm{j}=1}^{\mathrm{n}} \mathrm{w}_{\mathrm{j}} \mathrm{r}_{\mathrm{ij}}
$$

Gambar 2. Rumus Nilai Preferensi

Sumber : (Wicaksono, 2018)

Hasil perhitungan nilai Vi yang lebih besar mengidentifikasikan bahwa alternatif Ai merupakan alternatif terbaik.

\subsubsection{Koperasi}

Berdasarkan UU No 25 Tahun 1992 tentang Perkoperasian, koperasi adalah badan hukum yang didirikan oleh orang-seorangan atau badan hukum koperasi, dengan melandaskan kegiatannya berdasarkan prinsip koperasi sekaligus sebagai gerakan ekonomi rakyat yang berdasar atas asas kekeluargaan [6].

Menurut Triayudi \& Setiawan Hidayat, Koperasi atau Cooperative Organization bermakna organizatian owned by and operated for the benefit of those using its services atau dalam bahasa Indonesia diartikan bahwa organisasi koperasi adalah organisasi yang dimiliki sekaligus dioperasikan untuk kepentingan penggunaannya dalam hal ini adalah anggotanya [7].

Menurut Putri, Secara umum, tujuan dari pendirian koperasi adalah untuk meningkatkan kesejahteraan ekonomi para anggotanya. Namun, berdasarkan UU 1945 No. 25 pasal 3 menjelaskan bahwa tujuan koperasi Indonesia meliputi : (1) untuk memajukan kesejahteraan anggotanya, (2) untuk memajukan kesejahteraan masyarakat, dan (3) ikut serta membangun tatanan perekonomian nasional. [8]

\subsection{Metode}

Tahapan pengumpulan data yang digunakan dalam penelitian adalah studi literatur dan wawancara. Pada penelitian ini, metode pengembangan sistem yang digunakan adalah Rapid Application Development (RAD). Rapid Application Development (RAD) merupakan metode pengembangan sistem informasi dengan waktu singkat, sehingga dinilai tepat digunakan untuk membangun aplikasi koperasi yang berfokus pada satu pengguna. RAD menggunakan metode iteratif (berulang) dalam mengembangkan sistem dimana working model (model bekerja) sistem 
dikonstruksikan di awal tahap pengembangan dengan tujuan menetapkan kebutuhan (requirement) pengguna dan selanjutnya disingkirkan [9]. Dalam pengembangan sistem informasi normal, memerlukan waktu minimal 180 hari, namun dengan menggunakan metode RAD, sistem dapat diselesaikan dalam waktu 30-90 hari [10]. Metode ini memiliki 3 tahapan yaitu, requirement planning, desain sistem dan implementasi. Kerangka berpikir penelitian ini disajikan pada Gambar 3.

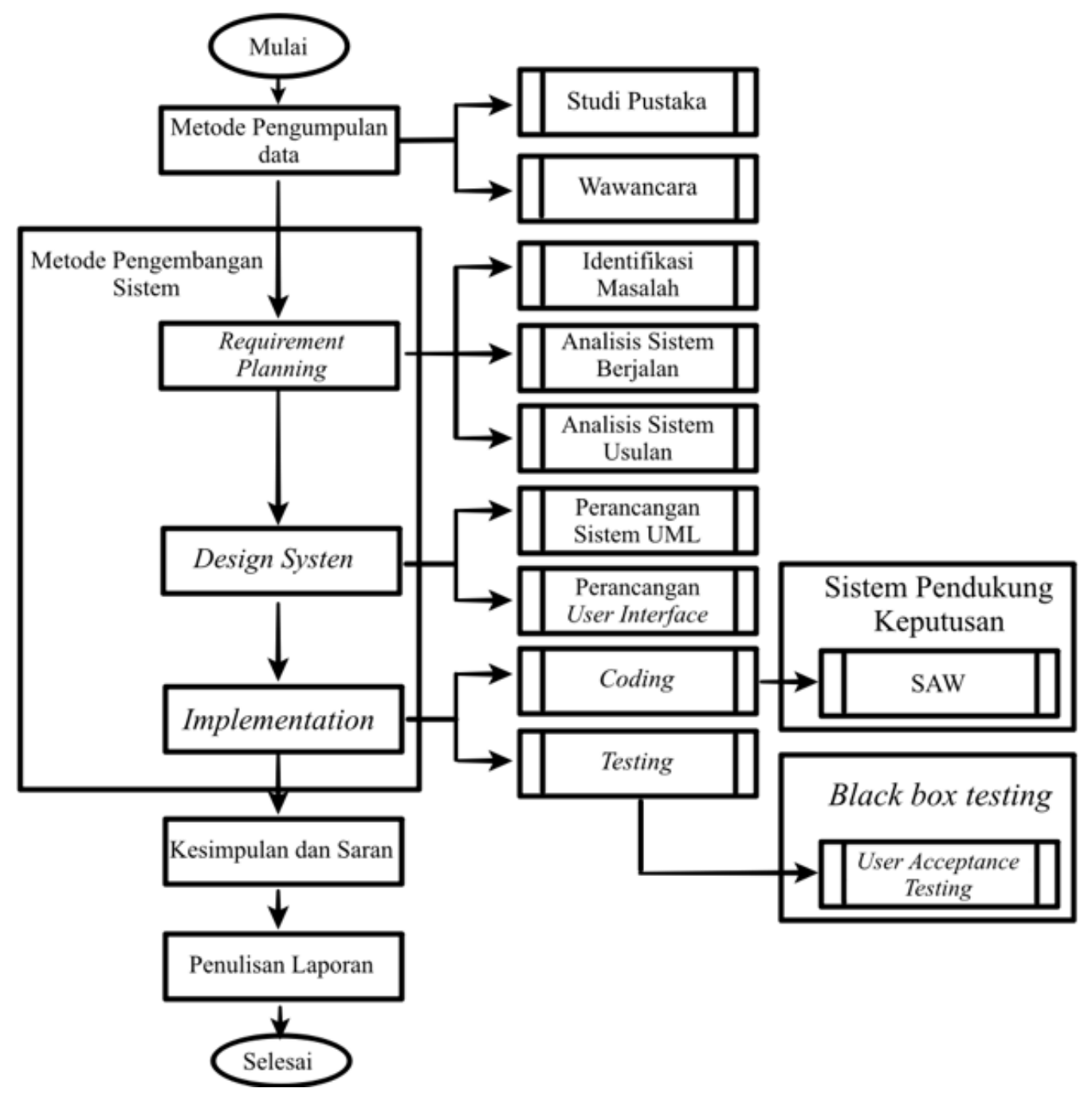

Gambar 3. Kerangka Berfikir 


\section{HASIL DAN PEMBAHASAN}

\subsection{Hasil Aplikasi}

\subsubsection{Menu Utama}

Menu utama adalah halaman awal muncul saat pertama kali aplikasi dijalankan. Halaman ini terdapat menu Daftar Anggota, Penilaian Anggota, dan Hasil. Menu utama aplikasi ini disajikan pada Gambar 4.

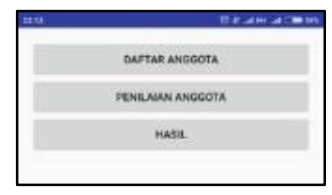

\section{Gambar 4. Halaman Menu Utama}

\subsubsection{Menu Daftar Anggota}

Tampilan halaman daftar anggota ini user dapat menambah anggota dengan menekan tombol (+) dan mengisi data anggota. Tampilan halaman daftar anggota disajikan pada Gambar 5.

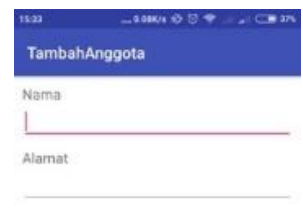

\subsubsection{Menu Penilaian}

\section{Gambar 5. Halaman Daftar Anggota}

Tampilan halaman penilaian ini user dapat menilai anggota dengan menekan nama anggota dan memberi nilai pada setiap kriteria. Tampilan halaman penilaian disajikan pada Gambar 6.

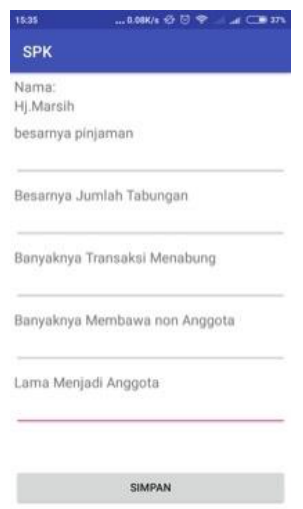

Gambar 6. Halaman Penilaian 
(c) Nenny Anggraini, Siti Ummi Masruroh, Muhammad Yusuf Nurpariz, Ariq Cahya Wardhana

\subsubsection{Menu Hasil}

Tampilan halaman hasil. ini user dapat melihat urutan nama anggota sesuai dengan nilai tertinggi sampai terendah. Tampilan halaman hasil disajikan pada Gambar 7.

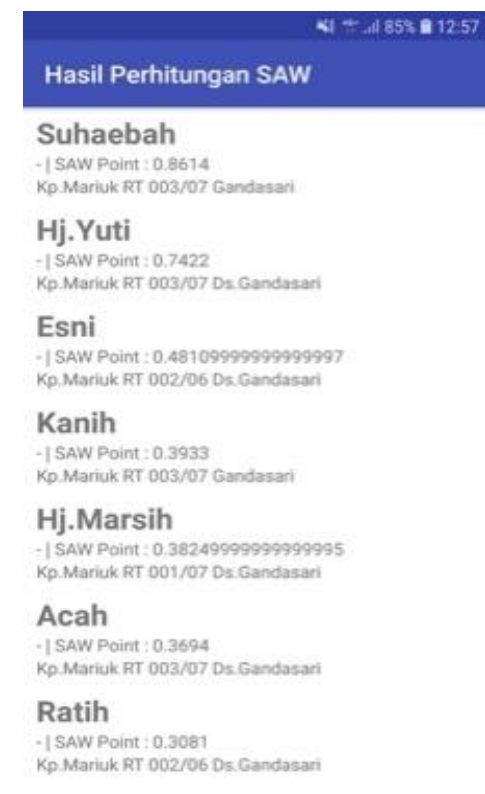

\subsection{Pembahasan}

Data alternative adalah 10 daftar nama anggota koperasi yang dijadikan sampel. Data alternative disajikan pada Tabel 1.

Tabel 1. Data Alternatif

\begin{tabular}{cc}
\hline Daftar Anggota & $\begin{array}{c}\text { Keterangan } \\
\text { (Alternatif) }\end{array}$ \\
\hline Hj. Marsih & A1 \\
Suai & A2 \\
Hj. Yuti & A3 \\
Kanih & A4 \\
Nani & A5 \\
Esni & A6 \\
Ratih & A7 \\
Diana & A8 \\
Acah & A9 \\
Suhaebah & A10 \\
\hline
\end{tabular}

Data kriteria adalah 5 jenis kriteria beserta bobotnya yang dijadikan parameter untuk menentukan anggota koperasi yang layak menerima hadiah. Data kriteria disajikan pada Tabel 2. 
Tabel 2. Data Kriteria

\begin{tabular}{ccc}
\hline Kriteria & Keterangan & Bobot \\
\hline C1 & Besarnya Jumlah Pinjaman & $30 \%$ \\
C2 & Banyaknya Jumlah Tabungan & $25 \%$ \\
C3 & Banyaknya Transaksi & $20 \%$ \\
C4 & Menabung & Lamanya Menjadi Anggota \\
C5 & Banyaknya Membawa Non & $15 \%$ \\
& Anggota & $10 \%$ \\
\hline
\end{tabular}

Tabel rating kecocokan ini berisi data setiap alternatif pada setiap kriteria. Table rating kecocokan disajikan pada Tabel 3.

Tabel 3. Rating Kecocokan

\begin{tabular}{crrrrr}
\hline \multirow{5}{*}{ Alternatif } & \multicolumn{5}{c}{ Kriteria } \\
\cline { 2 - 6 } A1 & \multicolumn{1}{c}{ C1 } & \multicolumn{1}{c}{ C2 } & C3 & C4 & C5 \\
\hline A2 & 1.000 .000 & 1.900 .000 & 9 & 75 & 11 \\
A3 & 50.000 .000 & 20.000 .000 & 4 & 111 & 1 \\
A4 & 20.000 .000 & 1.500 .000 & 3 & 143 & 6 \\
A5 & 4.000 .000 & 2.000 .000 & 7 & 75 & 1 \\
A6 & 5.000 .000 & 7.000 .000 & 9 & 143 & 7 \\
A7 & 10.000 .000 & 3.000 .000 & 2 & 143 & 3 \\
A8 & 2.000 .000 & 4.000 .000 & 6 & 75 & 2 \\
A9 & 5.000 .000 & 6.000 .000 & 8 & 99 & 3 \\
A10 & 50.000 .000 & 14.000 .000 & 12 & 143 & 4 \\
\hline
\end{tabular}

Hasil normalisasi berisi hasil perhitungan semua kriteria yang telah di normalisasi, yang nantinya akan dikalikan dengan bobot kriteria untuk dilakukan proses perankingan. Tabel hasil normalisasi disajikan pada Tabel 4. 
Tabel 4. Hasil Normalisasi

\begin{tabular}{llllll}
\hline & C1 & C2 & C3 & C4 & C5 \\
\cline { 2 - 6 } A1 & 0.1 & 0.095 & 0.75 & 0.524 & 1 \\
A2 & 0.02 & 0.025 & 0.167 & 1 & 0.182 \\
A3 & 1 & 1 & 0.333 & 0.776 & 0,091 \\
A4 & 0,4 & 0.075 & 0.25 & 1 & 0.545 \\
A5 & 0.08 & 0.1 & 0.583 & 0.524 & 0.091 \\
A6 & 0.1 & 0.35 & 0.75 & 1 & 0.636 \\
A7 & 0.2 & 0.15 & 0.167 & 1 & 0.273 \\
A8 & 0.04 & 0.2 & 0.5 & 0.524 & 0.182 \\
A9 & 0.1 & 0.3 & 0.667 & 0.692 & 0.273 \\
A10 & 1 & 0.7 & 1 & 1 & 0.364 \\
\hline
\end{tabular}

Hasil perangkingan berisi nilai akhir setiap anggota yang telah di proses dengan perhitungan metode SAW. Berdasarkan Tabel 5, maka didapat bahwa $v_{10}$ mempunyai nilai yang paling besar dengan nilai 0.861 . Dengan kata lain $v_{10}$ yang mengidentifikasikan alternatif $A_{10}$ adalah alternatif layak menerima hadiah tahunan dari koperasi Bunda. Data alternative disjaikan pada Tabel 5.

Tabel 5. Data Alternatif

\begin{tabular}{llll}
\hline$v_{1}=0.382$ & $v_{6}$ & $=0.481$ \\
$v_{2}$ & $=0.213$ & $v_{7}$ & $=0.308$ \\
$v_{3}$ & $=0.742$ & $v_{8}$ & $=0.258$ \\
$v_{4}$ & $=0.393$ & $v_{9}$ & $=0.369$ \\
$v_{5}$ & $=0.253$ & $v_{10}$ & $=0.861$
\end{tabular}

\section{KESIMPULAN}

Analisis Berdasarkan uraian dan pembahasan pada penelitian ini, dapat ditarik kesimpulan bahwa penerima hadiah tahunan koperasi Bunda ditentukan dengan lima kriteria yakni; besarnya jumlah pinjaman, banyaknya jumlah tabungan, banyaknya transaksi menabung, lama menjadi anggota dan banyaknya membawa nasabah non anggota dengan masing-masing bobot sebesar 30\%, 25\%, 20\%, 15\% dan 10\%. Dari 10 data sampel anggota koperasi, kemudian di proses dengan metode simple additive weighting (SAW) yang menghasilkan nilai tertinggi adalah $v_{10}$ dengan nilai 0,861 , yang artinya anggota koperasi tersebut layak menerima hadiah tahunan dari pihak koperasi. Dengan demikian sistem pendukung keputusan menggunakan metode simple additive weighting dapat memberikan solusi kepada pihak koperasi dalam menentukan anggota koperasi yang layak menerima hadiah tahunan. 


\section{REFERENSI}

[1] Aini, N., \& Agus, F. (2017). Penerapan Metode Weighted Product Dan Analytic Hierarchy Process Untuk Pemilihan Koperasi Berprestasi. Jurnal Informatika - Telekomunikasi Elektronika (INFOTEL), 9(2), 220-230.

[2] Mulyani, Y. (2017). Perancangan Sistem Pendukung Keputusan Kinerja Dosen Menggunakan Metode Simple Additive Weighting.

[3] Sari, F. (2018). Metode Dalam Pengambilan Keputusan. Yogyakarta: Deepublish.

[4] Latif, L. A., Jamil, M., \& Abbas, S. H. (2018). Sistem Pendukung Keputusan Teori Dan Implementasi. Yogyakarta: Deepublish.

[5] Wicaksono, S. R. (2018). Studi Kasus Sistem Penunjang Keputusan Metode SAW dan TOPSIS. Malang: CV.Seribu Bintang.

[6] Qurbani, D. (2015). Analisis Kinerja Koperasi Simpan Pinjam Berbasis Syari'ah Di Kabupaten Magelang Tahun 2011-2013.

[7] Triayudi, A., \& Setiawan Hidayat, F. (2016). Sistem Pendukung Keputusan Penentuan Penerima Pinjaman Modal Dana Bergulir Koperasi Simpan Pinjam Pada Diskoperindag Kabupaten Serang Menggunakan Metode Topsis. ProTekInfo, 3(1), 49-54.

[8] Putri, K. D. (2017). Analisis Tingkat Kesehatan Koperasi Simpan Pinjam (Studi Kasus pada Koperasi Simpan Pinjam Wisuda Guna Raharja, Lombok).

[9] Britton, Carol; Jill Doake. 2001.Object-Oriented Systems Development. McGraw-Hill. hlm. 28-29, 269. ISBN 0-07-709544-8.

[10] Noertjayana, A. 2002. Studi Analisis Rapid Application Development Sebagai Salah Satu Alternatif Metode Pengembangan Perangkat Lunak. Jurnal Informatika Vol.3, No.2, Nopember 2002:74-79 